\title{
Article \\ Implications of Climate Change on Outdoor Recreation: The Case of National Parks in Israel
}

\author{
Sharon Teitler Regev ${ }^{1, *}$ and Ruslana Rachel Palatnik ${ }^{1,2}$ (D) \\ 1 Department of Economics and Management, The Max Stern Yezreel Valley College, \\ Yezreel Valley 19300, Israel; rachelpa@yvc.ac.il \\ 2 Natural Resource and Environmental Research Center, University of Haifa, Haifa 31905, Israel \\ * Correspondence: sharont@yvc.ac.il
}

check for updates

Citation: Teitler Regev, S.; Palatnik, R.R. Implications of Climate Change on Outdoor Recreation: The Case of National Parks in Israel. Earth 2022, 3, 345-362. https://doi.org/10.3390/ earth3010021

Academic Editor:

Samuel Asumadu-Sarkodie

Received: 14 January 2022

Accepted: 16 February 2022

Published: 21 February 2022

Publisher's Note: MDPI stays neutral with regard to jurisdictional claims in published maps and institutional affiliations.

Copyright: () 2022 by the authors. Licensee MDPI, Basel, Switzerland. This article is an open access article distributed under the terms and conditions of the Creative Commons Attribution (CC BY) license (https:// creativecommons.org/licenses/by/ $4.0 /)$.

\begin{abstract}
Changing weather driven by climate change may influence tourists' decisions about "when and where to go for vacation." Indeed, the results of climate change have altered the attractiveness of a variety of destinations and locations, therefore changing the profitability of tourism-based businesses. The aim of the study was to evaluate the potential impact of climate change on visits to outdoor recreation sites. Specifically, the research assessed the impact of weather, as well as economic and other characteristics, on the number of domestic and international tourists visiting national parks located in different climate zones within a single country-Israel. This research was based on a unique database of actual daily visits by international and domestic tourists to national parks in Israel during a six-year period (2012-2017). Each national park has different accessibility characteristics and offers different attractions. The climate data included daily maximum temperature, rain, extreme weather, as well as temperature indices measuring heat and cold. The results of the econometric analysis showed that weather-related parameters have a statistically significant effect on national park visits among both domestic and international tourists, while the magnitude of the effect varies by park and visitors' place of origin.
\end{abstract}

Keywords: international and domestic tourism; climatic zones; outdoor recreation demand; climate change impact

\section{Introduction}

Climate change is expected to affect a wide variety of activities and have implications on economic growth, productivity, ecosystems, and sustainable development [1,2].

In the pre-COVID era, travel and tourism constituted one of the world's largest sectors. In 2019 , this sector accounted for $10.4 \%$ of the global GDP (USD 9.2 trillion) and 10.6\% of all jobs (334 million), and was responsible for creating one out of four new jobs across the world. Moreover, in 2019, international visitor spending amounted to USD 1.7 trillion, making it the third largest export category (6.8\% of total exports, $27.4 \%$ of global services exports) [3]. Even though COVID-19-related restrictions caused a significant decline in activity in this sector, recovery is expected around 2024 [4]. Moreover, domestic and regional vacations outdoors are already on the rise [5].

Yet, climate change (CC) may hamper this recovery. CC is characterized by an increase in extreme weather events, such as serious rain or droughts and uncharacteristically hotter or colder temperatures (Figure 1). Such events are already becoming more common [1]. Tourism is both a major contributor to CC (especially international travel) and one of the most affected sectors [6]. Changing weather driven by CC may influence tourists' decisions about their vacation timing and destination, alter the attractiveness of a variety of destinations and locations, and therefore change the profitability of tourism-based businesses [7]. 


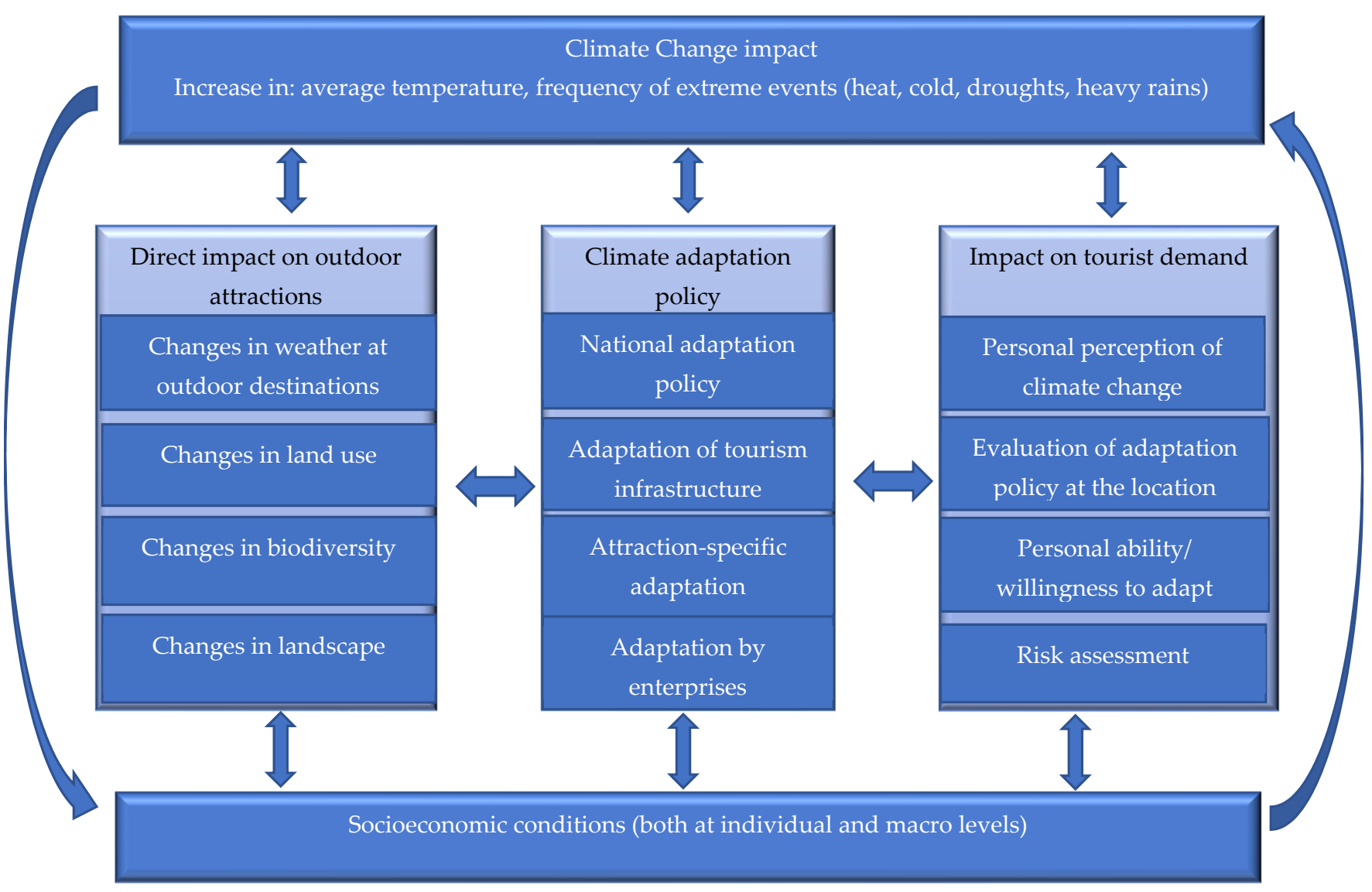

Figure 1. Links between climate change, adaptation, and tourist demand for outdoor attractions. Authors' adaptation based on Pröbstl-Haider et al. [6].

Figure 1 depicts the link between CC and tourist decision-making, a link that may lead tourists to select a different destination to avoid possible effects of CC [6]. The figure illustrates the main factors in this context, among which are the perceived impact of CC, climate policy, and adaptation strategies, but also the economic situation, which affects tourist demand in general and the demand for outdoor attractions in particular.

The implications of CC on outdoor recreation are theoretically ambiguous [2]. CC entails a rightward shift in the temperature distribution [1]. Therefore, outdoor activities in warmer regions where the temperature on hot days is expected to rise are projected to experience a reduction in demand. If, however, the climate in cooler areas becomes milder, these areas may experience an increase in demand for outdoor recreation [8,9]. Moreover, CC may lead to an increase in domestic trips, especially in colder countries [10]. Several empirical studies have shown that CC conditions will likely cause some destinations to gain and others to lose (e.g., $[6,11])$. Site-specific empirical analyses that consider weather conditions, visitors' preferences, and economic characteristics are needed to identify the net effect.

The aim of the current study was to evaluate the potential impact of CC on visits to attractions that are most vulnerable to weather conditions, namely outdoor recreation sites. Specifically, the research assessed the impact of weather, as well as economic and other characteristics, on the number of domestic and international tourists visiting national parks located in different climate zones within a given country.

Economic evaluation of the potential effects of CC on tourism attempts to quantify the effect of weather on tourism and to extrapolate this relationship into the future. A few key approaches have been applied [12]. The first methodology focuses on tourism climate indexes, which are used to evaluate the loss or gain in countries' competitiveness under CC $[13,14]$. Correlations found between current tourism demand, physical attributes, and 
climate indexes suggest that climate can be a predictor of tourist arrivals [6]. The second approach uses statistical models that relate tourism behavior to climate variables [15]. Another strand of research models tourism demand based on time-series analyses, discrete choice models, and aggregate tourism models [10]. These different approaches point to a nonlinear relationship between temperature and tourism demand, thus revealing the existence of optimal climatic conditions for tourism. Rosselló-Nadal [10] provided a comprehensive review of these methodological approaches.

Loomis and Crespi [9] conducted early research on the causal relationship between climate and recreational activity. They estimated how visitation rates for various recreation activities vary with weather conditions by coupling these estimations with climate projections from the Intergovernmental Panel on Climate Change (IPCC) and average consumer surplus values from the literature. The results showed overall benefits of USD 3 billion (in 1992 USD). Nevertheless, these researchers used aggregated regional measures of participation, relying on the cross-sectional variation across jurisdictions to pin down weather effects. This reliance on cross-sectional variation creates challenges for causal identification if local climates are correlated with recreational opportunities [2].

The results of a study in Hungary that used different versions of the Tourism Climatic Index indicated that tourism climate conditions for outdoor tourism purposes will likely improve in the shoulder seasons and deteriorate in the summer [16]. Agnew et al. [17] investigated the sensitivity of UK tourism to short-term climate variability by comparing the factors affecting international tourism to those that alter domestic tourism. They found that rain and temperature affect domestic tourism, while temperature has a lower effect on international visitors than rain or sunshine.

The potential impact of CC on business in the tourism sector has also been evaluated. For example, Craig et al. [7] analyzed longer-term climatic trends at 28 business locations in six different climate zones across the United States. Focusing on 13 business locations, they assessed the interaction between weather and categorical sales and found that favorable and adverse weather events affected overall sales forecasts by up to $3.6 \%$. Similarly, Day et al. [18] studied the effect of changes in the weather on the weekly revenue per available room and on some annual economic indicators (e.g., number of establishments, annual payroll, first quarter payroll, and number of employees) in five different locations in the United States. The results indicated that weather influenced economic performance in the short (weekly)- and medium (annual)-term.

Most studies on the effect of climate on tourism found that temperature, precipitation, and sunshine are the most important factors (e.g., [13,19-23]). Wilkins et al. [24] measured the effect of weather on tourists' expenditures in three geographically distinct locations in Maine, United States, using a nonparametric method. Their results showed that temperature was an influential predictor of tourism-related spending, while other weather variables had no statistically significant impact. In addition, warmer temperatures increased tourism spending in the summer and fall, but the results for the winter were ambiguous. Alternatively, the Atlantic climate is likely to gain from CC [25]. Pröbstl-Haider et al. [6] studied German tourists' intentions to travel to the Alps. The research tested the effect of additional days of sunshine on visits to the Alps during the summer. The results indicated that more days of sunshine affect only a few segments, compared to other destination attributes such as outdoor activities and nature experiences. Thus, tourists will most likely not switch to other destinations as a result of additional days of sunshine.

Atzori, Fyall, and Miller [26] focused on Florida, a very popular tourist destination with high vulnerability to CC. Using a quantitative survey, the researchers collected responses from 432 tourists who had previously visited Florida to a hypothetical scenario of changed climatic conditions. The results of the survey showed that tourists choose Florida because of the sunny weather and factors related to beach comfort. In a scenario in which beaches disappear and tropical diseases become frequent, most respondents stated they would choose a different destination. Nevertheless, the implementation of adaptive measures at the destination level may bring them back to Florida. 
In a study that sought to project future tourism patterns in Iran using different climate scenarios, Yazdanpanah et al. [27] focused on one of Iran's most beautiful tourist attractions - the Zayandehroud River route-and tested the tourism climate comfort (PET) at present and from 2014 to 2039, using the HadCM3 model for two A1B and B1 emission scenarios. The results indicated that a trend of rising temperatures leading to a decline in climate comfort will reduce the attractiveness of tourism destinations at the western end of the river.

Several studies focusing on the Mediterranean region forecasted that this region may become less attractive to tourists than the northern parts of Europe [13,28]. A study that focused on the Bay of Palma, Spain-a well-known destination for 3S' (Sea, Sun, and Sands) tourism - expanded the climate index for tourism (CIT). From what was originally designed for beach tourism, the CIT was extended to other types of recreation, such as cycling, cultural tourism, football, golf, motor boating, sailing, and hiking. The study concluded that if, as forecasted, weather conditions deteriorate during the peak period and improve in spring and autumn, CC could further exacerbate the present imbalance between seasonal distributions of ideal climate potentials and high attendance levels.

In this study, we add to the growing literature on the effects of CC on tourism. For the most part, our research is similar to the literature discussed above as we use short-term CC in combination with climate predictions to discuss potential future influences. Yet, our work is unique in that it generates causal estimates of the impact of weather on tourism using high-resolution data (both spatial and temporal). Therefore, our work is distinguished from the work of others in several major components.

This research examines the potential impact of climate on tourism using a time series analysis [10]. Employing the established methodology, the research builds on unique daily data on international and domestic tourists, while most previous studies relied on monthly data $[10,12,15]$. We use high-frequency data that were recorded in real time, constituting an advantage over traditional recreation studies that rely upon survey data.

The econometric evaluation is based on actual daily visits to five major national parks in Israel during the six-year period from 1 January 2012 to 31 December 2017, constituting about 11,000 observations. The data include the number of daily international and domestic visitors to national parks located in a variety of climatic zones (Figure 2). Each national park has different accessibility characteristics and attractions, e.g., nature reserves, archeological parks, cultural heritage, and more. We couple these highly detailed data on visitors with disaggregated climatic data, making it possible to parameterize the leisure-weather dose-response function for outdoor recreation. The climate data include daily maximum temperatures, rain, and extreme weather, as well as heat and cold indexes. We exploit within-country deviations in weather to estimate a causal, nonlinear relationship between weather and the resultant recreation demand.

This unique dataset allows us to answer a question that is rarely addressed for the case of international tourism. Most studies dealing with international tourism focus on tourists' decisions whether to travel to a given destination. This research focuses on their decision to visit an outdoor attraction after having chosen to travel to a particular country.

The results of the econometric analysis show that weather-related parameters have a statistically significant effect on visits of both domestic and international tourists, though the magnitude of the effect varies according to park and visitor origin. Moreover, climate policy and chosen adaptation strategies can influence visitors' decisions [6]. Whether and to what extent projected behavior can be influenced by economic incentives or new product developments is an open question that we address in the discussion.

\section{Materials and Methods}

We used Israel outdoor attractions as a case study for the analysis. Tourism is an economic sector with high potential to contribute to the Israeli economy. Before the COVID-19 crisis, the number of international tourists in Israel was on the rise, reaching a record of 4.55 million in 2019 [29] and an income of almost USD 6 billion. The tourism sector in 
Israel accounted for $2.4 \%$ of the GDP. As in most of the developed world, COVID restrictions dramatically reduced the inflow of international tourism in 2020 and 2021. Between closedowns, however, domestic tourists partially compensated for the reduction [30]. In the post-COVID-19 era, CC may impede further recovery of this sector. It is important to understand the magnitude of this potential impact as climate changes may hamper international tourist flow and radically damage projections for economic performance in the tourism sector. A long-term reduction in economic activity in this sector may harm the income potential of lower SES groups employed in this industry, thus increasing economic inequality.

We conducted the analysis using a unique database of daily data representing actual visits to tourist attractions located in different climatic zones in Israel. According to the Köppen-Geiger climate classification, this tiny country is characterized by three climatic zones: hot-summer Mediterranean (Csa), hot semi-arid (BSh), and hot desert climate (BWh) (Figure 2).

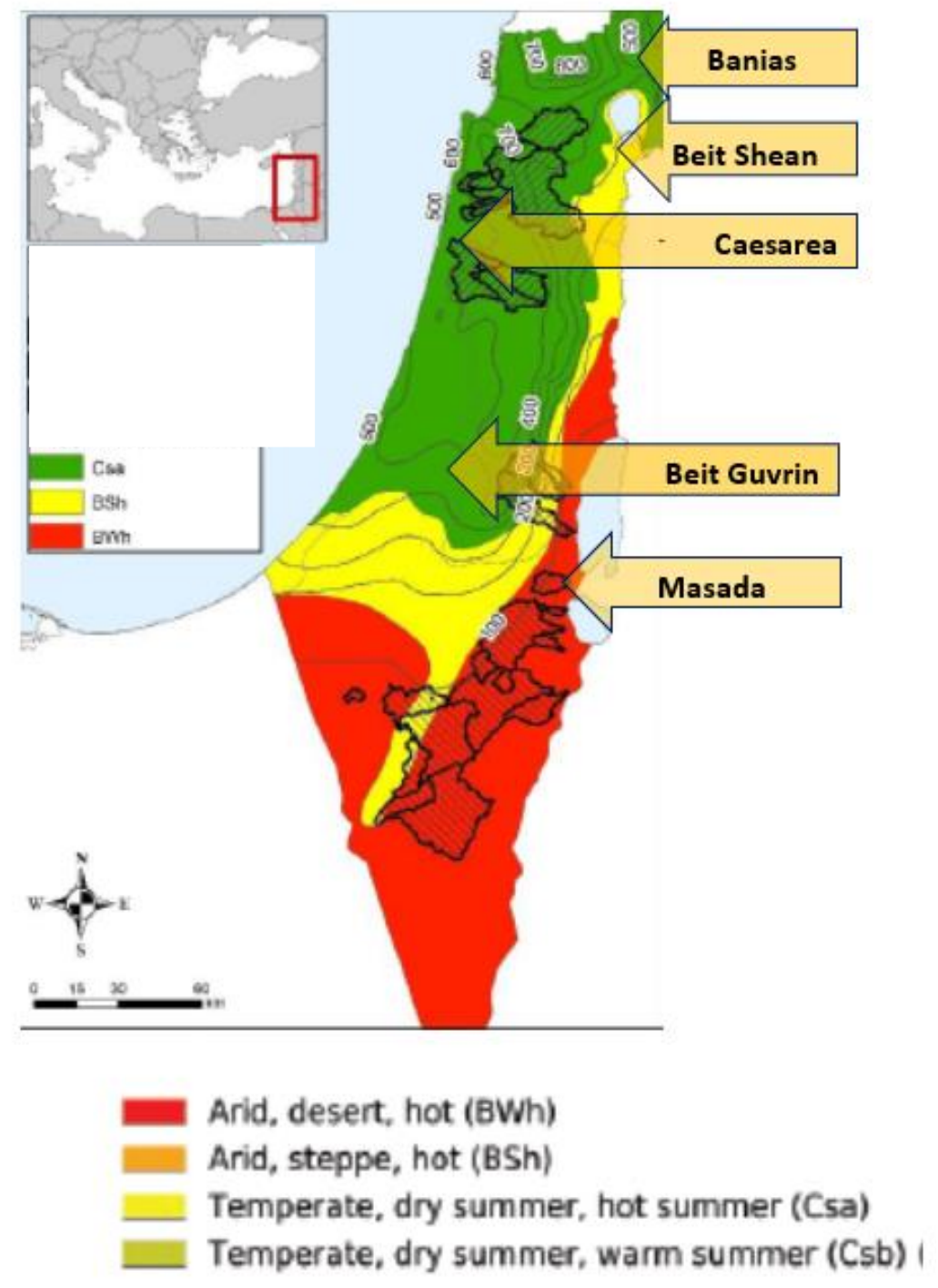

Figure 2. Köppen-Geiger climate classification from Survey of Israel (1970), mean annual precipitation (1981-2010, Israel Meteorological Services) (Source: [31]). 


\subsection{Characteristics of the National Parks}

The daily data for domestic tourism covered the period from 1 January 2012 to 31 December 2017, while for international tourism, the daily data ranged from 1 January 2014 to 31 December 2017. These data include the number of international and domestic visitors to the five main national parks in Israel: Banias nature reserve, Beit Shean, Caesarea, Beit Guvrin, and Masada. These national parks were chosen for several reasons: (a) they are the most visited national parks in Israel; (b) they are located in different areas of Israel-some in urban areas and some in rural areas-such that they differ in transport accessibility; (c) they are located in various climatic zones (Figure 2); (d) each national park has different attractions that appeal to visitors-nature reserves, archeological parks from various eras, and more. The following sections describe these five national parks, including location, type of attraction, weather conditions, and 2019 entrance fee given in USD.

Masada National Park is located in the Judean desert in southeastern Israel. The Masada fortress that was built in $30 \mathrm{BCE}$ by King Herod offers an archeological site with a heroic story. While the park is accessible by public transportation, the trip may take half a day from any major municipal center. The climate is dry (BWh) with less than $100 \mathrm{~mm}$ of precipitation per year [31]. The entrance fee is USD 8.8 for adults and USD 4.8 for children. The site can be accessed by cable car, which entails an additional fee.

Caesarea Antiquities National Park is located along the shore of the Mediterranean Sea at the center of the country. The antiquities in the park from the Roman city built by Herod show 2500 years of history and cultural continuity. The park is not far from Tel Aviv and is easily accessible by car or public transportation. The climate is typical Mediterranean (Csa) with dry summers and an average of 500-600 $\mathrm{mm}$ of precipitation per year [31]. The entrance fee is USD 11 for adults and USD 6.8 for children.

Bet Guvrin National Park is located in the conservation zone of Tel Maresha and features impressive remains from the times of the Bible and the Second Temple, as well as remains from the Roman and Crusader periods. The park is proclaimed to be the heart of the "land of thousand caves" in the southern Judean plains. It can be reached in about two hours by public transportation from Jerusalem. The climate is semi-arid (BSh) with hot and dry summers and less than $400 \mathrm{~mm}$ of rain per year during the winter months [31]. The entrance is USD 6.8 for adults and USD 3.4 for children.

Bet Shean National Park is located in the northeast part of Israel. The national park houses spectacular ruins reflecting the former glory of the Roman and Byzantine city of Bet Shean. Some of the remains go back to the Chalcolithic period. The park is accessible by public transportation, but the trip may take half a day from major urban centers (e.g., Haifa). It is located in a semi-arid climate (BSh). The weather is hot and dry, with less than $400 \mathrm{~mm}$ of rain per year [31]. The entrance fee is USD 6.8 for adults and USD 3.4 for children.

Banias-Nahal Hermon Nature Reserve is located in the eastern Upper Galilee on Israel's northern border, at the foot of Mount Hermon. The park contains the largest waterfall in Israel. The water flows all year long, with a trail suspended above it. The preserved archeological site contains the remains of the ancient city of Panyas. The climate is a typical Mediterranean climate (Csa), with dry summers and an average of 700-900 mm of rain per year [31]. The nature reserve is accessible by public transportation, but the trip may take half a day from any major urban center. The entrance is USD 6.8 for adults and USD 3.4 for children.

\subsection{Methods}

Our empirical goal was to examine the relationship between tourism demand for an outdoor attraction $(\mathrm{Y})$ and the weather $(\mathrm{W})$. In this, we conformed to empirical studies that utilized weather fluctuations to identify relationships between climate and economic outcomes [32]. Specifically, we sought to establish a causal relationship between weather outcomes and visits to national parks. We focused on two types of visitors, $Y_{\text {pymd }} \in$ $\left\{\right.$ IntTou $_{\text {pymd }}$, DomTou $\left._{\text {pymd }}\right\}$, to capture the number of international and domestic tourists 
visiting each of the parks on a given day. For each park, $p$, in our sample, we used separate regressions for domestic and international visitors at the daily level, $d$. We analyzed domestic and international tourists separately, as their preferences may be driven by different considerations [17].

To remove any long-term trends, all the numerical data were included in the model in natural $\log$ form. We tested the data for stationarity, which was not found. Although the entrance fees differ from park to park, they did not change over the research period and accordingly were not included in the regressions. We specified the following equation to link tourist demand for outdoor attractions and weather, while noting that we analyzed a variety of explanatory variables for robustness.

\subsubsection{Domestic Tourism Demand}

For domestic tourism, the model was:

$$
\ln \left(\text { DomTou }_{p d}\right)=W_{p d}+\lambda_{d}+\mu_{d}+\varepsilon_{p d}
$$

where $W_{p d}$ is a vector of climate indicators:

1. Daily maximum temperature in the area of the national park.

2. Daily maximum temperature squared.

3. Rain-mm daily in the area of the national park.

4. Extreme weather-a dummy variable - as defined by the Israel Meteorological Service

(IMS) [31] (the IMS issues a list of extreme weather events that include dates of extremely cold or hot days, and extraordinary amounts of rain or drought (IMS 2017)).

5. Heat Index temperature-considers the temperature and the wet bulb (humidity). The data are based on IMS data [31].

6. Cold index temperature-considers the temperature and the wind chill. The data are based on IMS data [31].

We detected multicollinearity between heat and cold indexes and the temperature. Accordingly, either temperature or heat/cold index was included in the regressions, based on the results that yielded the best fit of the model.

In Equation (1), $\mu_{d}$ is a vector of economic indicators:

Israeli tourists are likely to take exchange rate into consideration when deciding whether to travel abroad or domestically [17]. The major destinations for Israeli tourists abroad are the US and the European Union [33]. Accordingly, we used the euro exchange rate (daily exchange rate measured in local currency, ILS, per euro) and the USD exchange rate (daily exchange rate of ILS per USD). The higher the exchange rate, the costlier traveling abroad becomes relative to domestic recreation. For Saturday and Sunday, the value of Friday was used [34].

The cost of commuting may become significant for domestic tourists when considering a visit to remote locations. Therefore, daily oil prices were used as a proxy for domestic travel costs (for Friday and Saturday, the value of Thursday was used) [35]. These considerations are less relevant for international tourists, who usually plan their visit in advance based on characteristics of the attractions they intend to visit.

Income data are based on average monthly wage calculated on a daily basis [36]. Earlier research found that income may affect domestic tourism $[37,38]$.

$\lambda_{d}$ is a vector of dummy variables:

Dummy variables for weekdays vs. weekends and holidays were added, as weekends may be more crowded with domestic visitors.

Risk is a dummy variable that represents whether there was a terrorist incident with casualties on a particular day. We also included lagged risk variables for the next seven days as a terrorist incident can have a negative effect on park attendance on subsequent days as well. The effect of terrorism on tourism has been researched extensively $[39,40]$. This variable may reflect general hostility, which may prevent tourists from visiting certain attractions [41]. 


\subsubsection{International Tourism Demand}

To analyze international tourists' demand for outdoor attractions, the following model was used:

$$
\ln \left(\operatorname{IntTou}_{p d}\right)=W_{p d}+\mu_{d}+\lambda_{d}+\alpha_{d}+\varepsilon_{p d}
$$

The set of variables for international tourism is somewhat different than for domestic tourism [17]. This is because international tourists' decisions to visit national parks are a supplementary product of their decision to visit the country of destination. The decision whether to visit a national park is usually made after the tourist arrives in the destination country. Therefore, variables such as income and oil prices, which may affect the decision to visit Israel, are irrelevant once an international tourist arrives in Israel. Accordingly, the vector of economic indicators, $\mu_{d}$, includes the euro and USD exchange rates as a proxy for relative price levels. Here, we expect a positive impact, as an increase in the exchange rate means that the purchasing power of the foreign traveler's currency increases and, therefore, expenses in Israel become relatively cheaper.

The vectors of climate indicators, $W_{p d}$, and the dummy variables $\lambda_{d}$ are the same as for domestic tourism. In addition, the number of international tourists in Israel at any given day, $\alpha_{d}$, can affect the number of visitors as it represents the overall potential. The average length of stay in Israel is ten days [42]. Accordingly, we used the number of international tourists in Israel as a lagged variable from lag1 (lag of one day) to lag 9 (lag of 9 days).

\subsection{Data}

Figure 3 depicts the distribution of daily maximum temperatures at each national park.

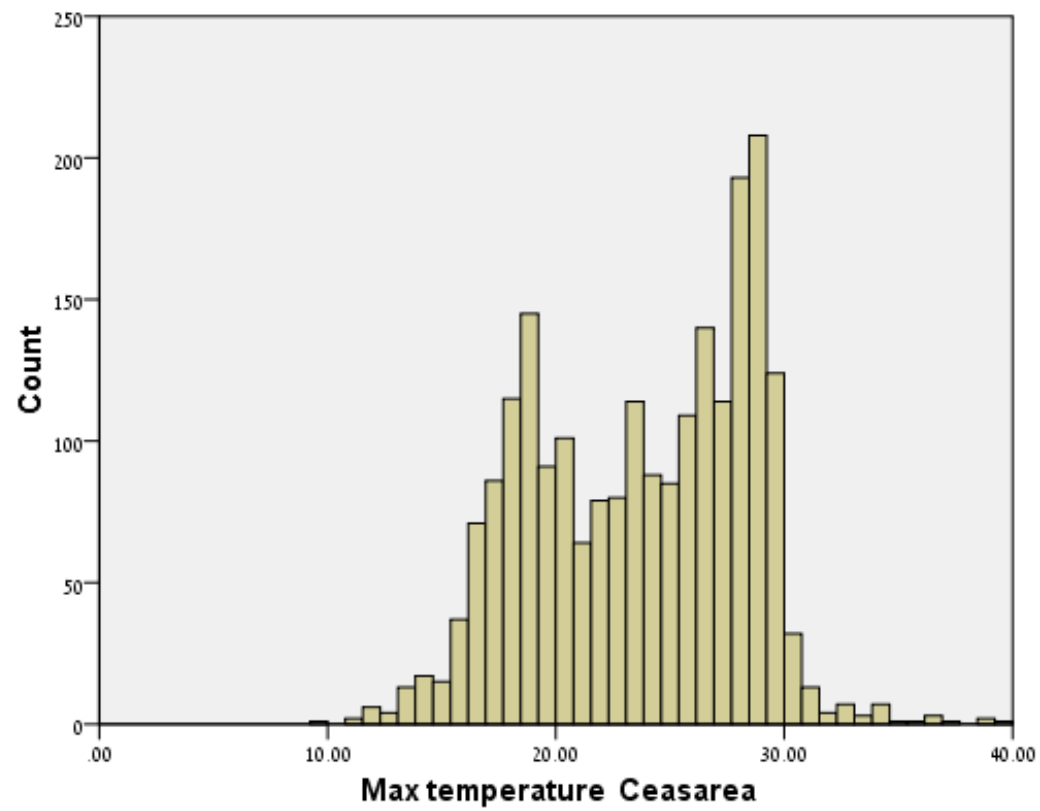

Figure 3. Cont. 

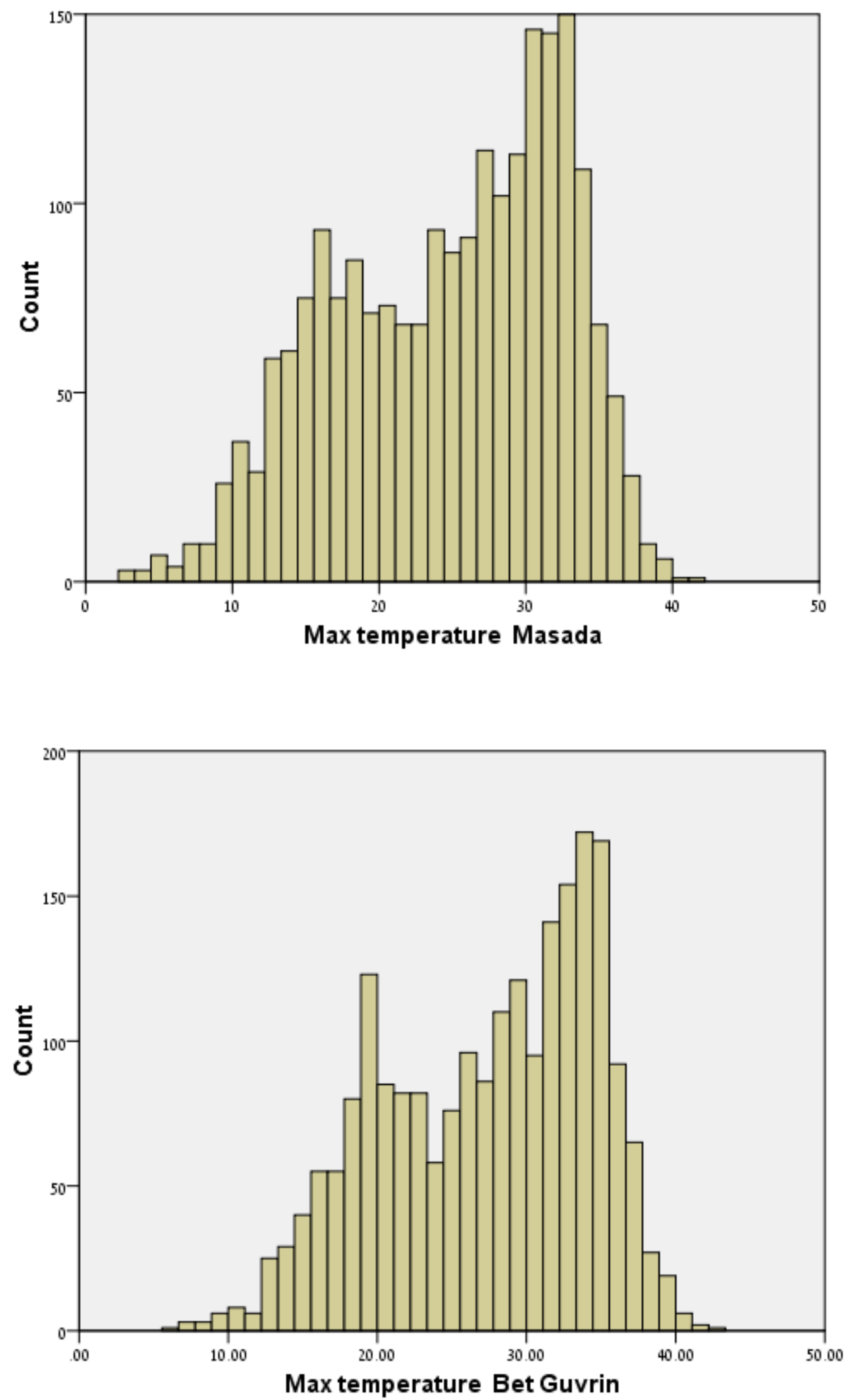

Figure 3. Cont. 

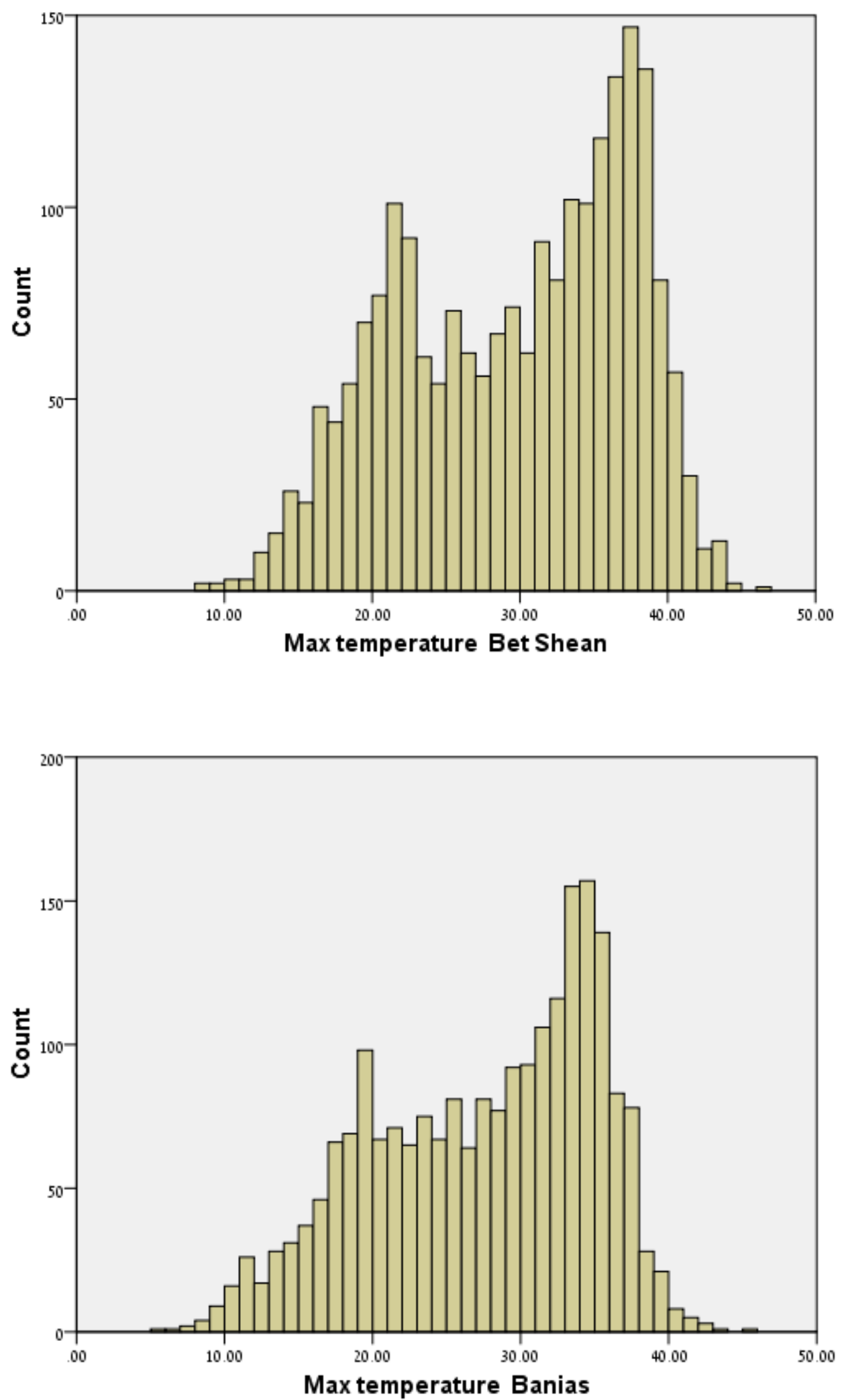

Figure 3. Maximum temperature distribution in the national parks in the period of the study.

This research included several data sources (Appendix A). Table 1 summarizes the descriptive statistics of the data. For the domestic tourism, the daily data ranged from 1 January 2012 to 31 December 2017, while for the international tourism, the daily data ranged from 1 January 2014 to 31 December 2017. 
Table 1. Descriptive statistics of the data.

\begin{tabular}{|c|c|c|c|c|c|}
\hline & & Average in the Period & St. D. & Min & Max \\
\hline \multirow{4}{*}{ 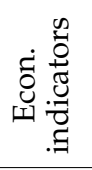 } & Euro exchange rate (daily) & 4.52 & 0.34 & 3.86 & 5.11 \\
\hline & USD exchange rate (daily) & 3.73 & 0.165 & 3.4 & 4.1 \\
\hline & Average Wage (in ILS, daily average) & 312.35 & 15.8 & 282 & 356 \\
\hline & Price of Oil (USD 2015) & 71.02 & 25.1 & 26.21 & 110.53 \\
\hline \multirow{6}{*}{$\begin{array}{l}\frac{\pi}{\pi} \\
\mathbb{\pi} \\
\sum \\
\Sigma\end{array}$} & \# International visitors Masada (daily) & 1188 & 590 & 0 & 4789 \\
\hline & \# Domestic tourism Masada (daily) & 617 & 412 & 0 & 4625 \\
\hline & Temperature Masada (Celsius) & 24.8 & 7.7 & 3 & 42 \\
\hline & Rain Masada (mm) & 0.75 & 3.9 & 0 & 55 \\
\hline & Cold Index Masada & 0 & 0 & 0 & 1 \\
\hline & Heat Index Masada & 1.84 & 1.96 & 0 & 5 \\
\hline \multirow{6}{*}{ 志 } & \# International visitors Bet Guvrin (daily) & 1000 & 493 & 0 & 3943 \\
\hline & \# Domestic tourism Bet Guvrin (daily) & 974 & 945 & 0 & 9049 \\
\hline & Temperature Bet Guvrin (Celsius) & 23.73 & 4.7 & 9.4 & 39.5 \\
\hline & Rain Bet Guvrin (mm) & 1.46 & 6 & 0 & 89 \\
\hline & Cold Index Bet Guvrin & 0 & 0 & 0 & 1 \\
\hline & Heat Index Bet Guvrin & 1.56 & 1.88 & 0 & 5 \\
\hline \multirow{6}{*}{ 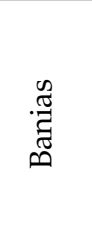 } & \# International visitors Banias (daily) & 611 & 363 & 0 & 2403 \\
\hline & \# Domestic tourism Banias (daily) & 835 & 690 & 0 & 10,437 \\
\hline & Temperature Banias (Celsius) & 27.5 & 7.5 & 5.9 & 45.2 \\
\hline & Rain Banias (mm) & 1.73 & 6.9 & 0 & 103 \\
\hline & Cold Index Banias & 0 & 0 & 0 & 2 \\
\hline & Heat Index Banias & 2.12 & 2.13 & 0 & 5 \\
\hline \multirow{6}{*}{ 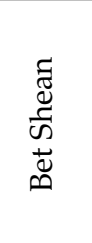 } & \# International visitors Bet Shean (daily) & 265 & 278 & 0 & 9054 \\
\hline & \# Domestic tourism Bet Shean (daily) & 158 & 217 & 0 & 3259 \\
\hline & Temperature Bet Shean (Celsius) & 29.65 & 7.8 & 8.2 & 46.3 \\
\hline & Rain Bet Shean (mm) & 0.97 & 4.29 & 0 & 64 \\
\hline & Cold Index Bet Shean & 0 & 0 & 0 & 2 \\
\hline & Heat Index Bet Shean & 2.36 & 2.2 & 0 & 5 \\
\hline \multirow{6}{*}{ 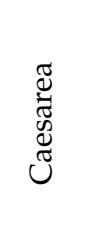 } & \# International visitors Caesarea (daily) & 1000 & 493 & 0 & 3943 \\
\hline & \# Domestic tourism Caesarea (daily) & 974 & 945 & 0 & 9049 \\
\hline & Temperature Caesarea (Celsius) & 23.73 & 4.7 & 9.4 & 39.5 \\
\hline & Rain Caesarea $(\mathrm{mm})$ & 0.754 & 6.04 & 0 & 89 \\
\hline & Cold Index Caesarea & 0 & 0 & 0 & 1 \\
\hline & Heat Index Caesarea & 1.56 & 1.88 & 0 & 5 \\
\hline
\end{tabular}

\section{Results}

In the following section, we report the results of our analysis of the factors affecting international and domestic tourists' decisions to visit each of the parks. For each park, we chose the best model according to goodness of fit.

\subsection{International Tourism}

Table 2 shows the results of the statistically significant explanatory variables influencing international tourists' demand to visit each national park.

The results point to a variation in the factors influencing the demand to visit the national parks under investigation. 
Table 2. Regression results for the number of international tourists visiting each national park (dependent variable in natural log form).

\begin{tabular}{|c|c|c|c|c|c|}
\hline Explanatory Var. & Caesarea & Bet Shean & Banias & Masada & Bet Guvrin \\
\hline Euro & $1.2 *(0.18)$ & $1.39 *(0.34)$ & - & $0.59 *(0.2)$ & - \\
\hline USD & $1.22 *(0.25)$ & - & - & $1.11 *(0.27)$ & - \\
\hline Temp & - & $-0.78 *(0.22)$ & $-0.47 *(0.08)$ & $-0.57 *(0.12)$ & $-1.23 *(0.33)$ \\
\hline Temp ${ }^{2}$ & - & $-0.07^{* * *}(0.036)$ & - & $0.04 *(0.02)$ & $0.21 *(0.05)$ \\
\hline Rain & $-0.045 *(0.02)$ & $-0.13 *(0.03)$ & $-0.08^{* *}(0.02)$ & $-0.04 *(0.02)$ & - \\
\hline Extreme & $0.07^{* * *}(0.04)$ & - & - & $-0.20 *(0.04)$ & - \\
\hline Cold level & - & - & - & - & - \\
\hline Heat level & $-0.02 *(0.03)$ & - & - & - & - \\
\hline Risk & $0.04^{* *}(0.01)$ & - & - & - & - \\
\hline Weekend & $-0.09 *(0.01)$ & $-0.11 *(0.02)$ & $-0.10 *(0.02)$ & - & - \\
\hline $\begin{array}{l}\text { Lag of int. tourists } \\
\text { in country (day } 1 \text { ) }\end{array}$ & $0.14 *(0.02)$ & 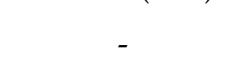 & $0.21 *(0.03)$ & $0.12 *(0.02)$ & $0.09^{* * *}(0.05)$ \\
\hline $\begin{array}{l}\text { Lag of int tourists } \\
\text { in country (day 2) }\end{array}$ & $\begin{array}{c}0.14 *(0.00) \\
-\end{array}$ & - & $0.12 *(0.03)$ & $0.07 *(0.02)$ & $0.10^{* * *}(0.04)$ \\
\hline $\begin{array}{l}\text { Lag of int tourists } \\
\text { in country (day } 3)\end{array}$ & - & $0.28 *(0.03)$ & $0.11^{* *}(0.03)$ & $0.11 *(0.02)$ & - \\
\hline $\begin{array}{l}\text { Lag of int tourists } \\
\text { in country (day } 4)\end{array}$ & $0.08 *(0.018)$ & $0.21 *(0.037)$ & $0.06^{* * *}(0.029)$ & $0.1 *(0.02)$ & - \\
\hline $\begin{array}{l}\text { Lag of int tourists } \\
\text { in country (day 5) }\end{array}$ & $0.04^{* * *}(0.022)$ & $0.12 * *(0.038)$ & $0.06^{* * *}(0.028)$ & $0.05 *(0.02)$ & - \\
\hline $\begin{array}{l}\text { Lag of int tourists } \\
\text { in country (day 6) }\end{array}$ & $0.09 *(0.02)$ & $0.18 *(0.04)$ & - & $0.17 *(0.02)$ & - \\
\hline $\begin{array}{l}\text { Lag of int tourists } \\
\text { in country (day } 7 \text { ) }\end{array}$ & $0.06^{* *}(0.02)$ & - & $0.07 * *(0.02)$ & - & - \\
\hline $\begin{array}{l}\text { Lag of int tourists } \\
\text { in country (day } 8 \text { ) }\end{array}$ & - & $0.12 *(0.04)$ & - & $0.07 *(0.02)$ & $0.27 *(0.05)$ \\
\hline $\begin{array}{l}\text { Lag of int tourists } \\
\text { in country (day 9) }\end{array}$ & $0.08 *(0.02)$ & - & - & - & $-0.13^{* * *}(0.06)$ \\
\hline Adj. $R^{2}$ & 0.491 & 0.358 & 0.318 & 0.473 & 0.064 \\
\hline $\mathrm{N}$ of observations & 1432 & 1433 & 1429 & 1418 & 1369 \\
\hline
\end{tabular}

$p$-Value ${ }^{*} p<0.001 ; * * 0.01 ;{ }^{* * *} p<0.05$.

\subsubsection{Climate Conditions}

Temperature has a statistically significant negative effect on international visitors to all the parks except Caesarea. Moreover, for tourists visiting Masada and Bet Guvrin, the square of the temperature is positive, while for those visiting Bet Shean, it is negative. Visiting Caesarea is negatively affected not by the temperature, but rather by the heat level. This can be explained by the fact that Caesarea is located on the shores of the Mediterranean Sea, where the temperature may be less influential than at other locations unless the heat conditions, which consider humidity levels in addition to temperature, are extremely high

Rain has a negative effect on all the parks except Bet Guvrin. Extreme weather has a negative effect on visitors to Masada, which is located in the desert. The surprising positive effect of extreme weather on international tourists visiting Caesarea can be explained by its central location on the shore.

\subsubsection{Economic Parameters}

The euro exchange rate has a positive effect on international tourists' demand to visit all the parks, except Bet Guvrin and Banias. When the exchange rate is high, tourists receive more domestic currency (ILS) per euro. Therefore, if the Israeli shekel has depreciated, expenses in Israel become relatively cheaper for international visitors, as do entrance fees to the national parks, such that the number of visitors increases. The elasticity of demand ranges from 0.59 for Masada to 1.39 for Bet Shean. The results are similar for the USD 
exchange rate, but its impact is statistically significant only for Masada and Caesarea, parks with higher entrance fees.

The number of international tourists arriving in Israel (lag of international tourists in the country) has an impact on all the national parks, but each park is affected on a different day from arrival. Caesarea and Bet Guvrin are mainly visited at the beginning or the end of tourists' stay, as the statistically significant lags are 1,2 and 8,9 for these parks, respectively. A possible explanation may be the relative proximity of these two parks to the major international airport and to Jerusalem and Tel Aviv, the most visited cities in Israel [33]. The other parks are located in remote areas at the north and south of the country, possibly explaining the statistically significant lags concentrated mainly a few days after arrival or before departure.

Risk exerts a positive effect only on Caesarea, perhaps due to Caesarea's central location and its relative proximity to Tel Aviv. The other national parks, in contrast, are located far from the center, perhaps mitigating the impact of internal tensions on visitor demand. Lagged risk variables were insignificant for international visitors and therefore not reported in Table 2.

The weekend has a negative effect on demand among international visitors to Caesarea, Bet Shean, and Banias. That is, international tourists prefer visiting these sites on weekdays. This preference has two possible reasons: (1) those sites may be less crowded on weekdays; (2) for tourists using public transportation, weekdays are the only option to visit those sites due to the lack of public transportation on weekends.

\subsection{Domestic Tourism}

Table 3 shows the results of the statistically significant explanatory variables influencing domestic tourist demand to visit each national park (dependent variable in natural log form). In general, the results for domestic tourist demand for visiting national parks are more homogeneous than those for international tourists. Nevertheless, the strength of the impact varies.

Table 3. Regression results for the number of domestic tourists visiting each national park.

\begin{tabular}{|c|c|c|c|c|c|}
\hline Explanatory Var. & Caesarea & Bet Shean & Banias & Masada & Bet Guvrin \\
\hline Euro & $3.75 *(0.47)$ & $-2.61 *(0.44)$ & - & $2.83 *(0.28)$ & $-3.75 *(0.7)$ \\
\hline USD & $1.59^{* * *}(0.67)$ & $-1.24^{* * *}(0.51)$ & - & $-1.17 *(0.33)$ & $1.59 * * *(0.67)$ \\
\hline Temp & $-2.4 *(0.28)$ & $-0.96^{* *}(0.23)$ & $-2.21 *(0.17)$ & $-1.11 *(0.144)$ & $-2.44 *(0.28)$ \\
\hline Temp ${ }^{2}$ & $0.27 *(0.05)$ & $0.1^{* *}(0.04)$ & $0.42 *(0.03)$ & $0.09 *(0.02)$ & $0.27 *(0.05)$ \\
\hline Rain & $-0.2 *(0.04)$ & $-0.18 *(0.03)$ & $-0.2 *(0.03)$ & - & $-0.2 *(0.04)$ \\
\hline Extreme weather & $-0.39 *(0.08)$ & $-0.32 *(0.07)$ & $-0.12^{* * *}(0.05)$ & $-0.38 *(0.04)$ & $-0.39 *(0.08)$ \\
\hline Risk & $-0.41^{* *}(0.03)$ & - & $-0.8 *(0.02)$ & $-0.05 *(0.02)$ & $-0.13 *(0.03)$ \\
\hline Risk2 & $-0.08^{* * *}(0.03)$ & - & $-0.08 *(0.02)$ & - & $-0.08^{* * *}(0.03)$ \\
\hline Risk4 & $-0.1^{* *}(0.03)$ & $-0.1 *(0.02)$ & $-0.1 *(0.02)$ & - & $-0.1^{* *}(0.03)$ \\
\hline Risk5 & - & - & - & $-0.44^{* * *}(0.02)$ & - \\
\hline Risk6 & - & - & - & $-0.39 * * *(0.02)$ & - \\
\hline Risk7 & $-0.11^{* *}(0.03)$ & - & - & $-0.04^{* * *}(0.02)$ & $-0.11^{* *}(0.03)$ \\
\hline Weekend & $0.25^{* * *}(0.15)$ & $-0.04^{* * *}(0.02)$ & $0.16 *(0.02)$ & - & $0.25 *(0.02)$ \\
\hline income & - & $-2.89(0.66)$ & - & $-0.5^{* * *}(0.18)$ & - \\
\hline Income $^{2}$ & $-0.68 *(0.18)$ & - & $-1.25 *(0.164)$ & - & - \\
\hline Poil & $-0.34^{* * *}(0.15)$ & - & - & - & $-0.34^{* * *}(0.15)$ \\
\hline Adj. $R^{2}$ & 0.171 & 0.06 & 0.258 & 0.145 & 0.171 \\
\hline $\mathrm{N}$ of observations & 2132 & 2152 & 2159 & 2132 & 2132 \\
\hline
\end{tabular}

$p$-Value ${ }^{*} p<0.001 ;{ }^{* *} p<0.01 ;{ }^{* * *} p<0.05$.

\subsubsection{Climate Conditions}

Temperature has a significant negative effect on domestic demand for all natural reserves. When the temperature increases, the demand of domestic tourists for these 
national parks declines. In addition, the square of the temperature has a positive effect at all the reserves.

Rain has a negative effect on domestic demand for all parks but Masada. A possible explanation may be that Masada is situated at the heart of a dry desert with very little rainfall. Extreme weather has a statistically significant negative effect on domestic demand for visiting all the reserves.

\subsubsection{Economic Conditions}

An increase in the euro or USD exchange rate reflects a depreciation in the domestic currency. A decrease in the euro exchange rate has the opposite effect at all the reserves except Banias. The results are similar for the USD exchange rate for Masada and Beit Shean, while for Bet Guvrin and Caesarea, the USD has a positive effect.

Income has a negative effect only on visits to Masada and Bet Shean, possibly reflecting the popularity of these remote attractions among visitors aged 13-20 who are hiking the Israel National Trail, which traverses Israel from its southern to its northern border. Hiking the Israel Trail has become popular among teens celebrating a Bar Mitzvah and among young people before joining the army [43]. The income elasticity of demand is -0.5 for domestic visitors to Masada and -2.89 for domestic visitors to Bet Shean. The effect of income squared on Banias and Caesarea is negative, perhaps because visits to these national parks are less expensive than other attractions.

As expected, oil prices increase costs and deter people from traveling to remote outdoor attractions. The domestic demand for visiting Caesarea and Bet Guvrin declines when the price of oil increases, with an elasticity of -0.34 in both cases.

On the day of a terrorist incident and up to a week later, risk has a negative impact on domestic demand for all national parks. The weekend has a negative effect on the number of tourists to Bet Shean and a positive effect on the number of Israelis visiting Caesarea, Bet Guvrin, and Banias. That is, Israelis prefer to visit Bet Shean on weekdays. This may be because this site is popular among organized groups, while Caesarea, Bet Guvrin, and Banias are mostly visited on weekends by families with children.

In addition, the above results point to both similarities and differences between the factors affecting international and domestic tourism. For example, the impact of risk on Israelis is negative (when it is significant), while risk largely does not affect international tourists (except for a positive effect in the case of Caesarea). Israelis can postpone their visits to national parks, while tourists that visit Israel for a short time cannot. The effect of day of the week is also different. While international tourists prefer to visit the national parks on weekdays, domestic tourists prefer to visit the sites (except Bet Shean) on weekends.

When it comes to the weather, however, the effects are mostly similar. Both rain and higher temperatures reduce tourist demand. One interesting finding is that the temperature elasticity of domestic demand is much higher than that of international demand.

\section{Discussion}

Climate change has the potential to induce a wide range of socioeconomic impacts that can have direct and indirect effects on tourism demand. The health of the human ecosystem is dependent on biotic health (organisms and ecosystems) and abiotic elements (climate and geomorphology) [43]. For instance, an increase in air and seawater temperatures will, in turn, increase the spread of airborne and waterborne diseases and change the distribution of species [44]. Given the recent pathogen-related concerns for tourism such as the COVID-19 virus outbreak, major disruptive environmental changes have the potential to exert a rapid impact on the global tourism economy in the future.

Although the economic impact of CC on the tourism sector has been extensively investigated, our understanding of the impact of climate on outdoor attractions remains incomplete [2]. The aim of this research is to study various weather conditions to determine the potential impact of CC on domestic and international tourism. Specifically, we track the impact of weather, as well as economic and other conditions, on the number of domestic 
and international tourists visiting national parks. Our case study is based on data reflecting international and domestic tourist demand for national parks in Israel. Even though Israel is a very small country and can be traversed from the north to the south in about six hours, the country contains three different climate zones.

We use a unique database of actual daily visitors to five outdoor attractions located in different climatic zones. The results for Masada can be considered representative of outdoor locations in desert areas. The climate in the Banias and Caesarea national parks is defined as Mediterranean (Csa), with Banias resembling northern Mediterranean countries and Caesarea representing onshore eastern Mediterranean locations. Bet-Guvrin and Bet Shean are located in the inner areas of the country, with semi-arid climates similar to those found in Africa, Australia, North America, and South Asia.

Rainfall and temperature indices are appropriate climate indicators of domestic and international tourism. In general, our results point to a negative association with rainfall. Of the climate variables considered, temperature clearly has the most important negative influence on domestic and international tourism decisions. If conditions are warmer than normal, tourism levels decline. International tourism is generally less spontaneous than domestic tourism, with bookings made well in advance of the time of travel [17]. It is therefore not surprising that the short-term association between climate and tourism is stronger for domestic tourism. In the long term, however, international tourists may alter their preferences to avoid hotter climates, such that they will take fewer trips to Israel in general.

According to climate projections, the average temperature in Israel will increase by $2{ }^{\circ} \mathrm{C}$ by the year 2050. Assuming that visitors' preferences are not altered by climate change, the research results indicate that the number of international and domestic tourists to outdoor recreation sites in Israel will significantly decline. For example, at Ben Guvrin, the increase in temperature driven by climate change will significantly reduce both domestic and international tourism. Hence, the tourism industry should already begin strategic planning in terms of developing new infrastructures and detecting mid- and long-term business opportunities [10].

This research has some limitations. One is that it focuses on a single country, Israel, such that caution should be taken when relating these results to other countries. In addition, to further investigate the potential impact of climate change on the demand for outdoor recreation, we recommend conducting a panel data analysis complemented by a survey of tourists' preferences. Such a survey can provide additional information about the factors that have the potential to influence the demand for outdoor recreation. For example, whether tourists use public transportation or rent a car can influence whether they have access to the national parks. Moreover, a park's proximity to the major cities in Israel or to other points of interest can influence visitors' decisions. Tourists' vacation preferences, e.g., hiking, visiting historical or archeological sites, or visiting holy places, may also influence demand. Including this type of information in the analysis can shed more light on tourists' decisions and may change the regression results, altering the projected effects of the climate parameters.

Although the analysis is indicative of the potential impact of generally warmer and drier conditions on present-day tourism, historical analogs should not be viewed in isolation, but should be considered in conjunction with future scenarios of how social and economic conditions may evolve in future decades (Figure 1).

There is no doubt that climate variability and change are both issues that should be of concern to the tourism industry, as illustrated by the analysis presented in this study. Currently, these challenges are perceived in the industry as long-term global problems in a sector typified by short-term strategic decisions [17]. Tourism models of climate sensitivities based on real data provide a baseline against which estimations of adaptive responses to future climate variability should be made.

As long as climate sensitivities are identified and modeled at appropriate scales of analyses and the interrelationships between climate, tourism, and other environmental, 
social, economic, and political factors are evaluated, it is likely that the tourist industry will be able to adapt to future CC. The experiences surrounding COVID-19 have shown that normative instruments do have the power to bring about significant trend reversals, including changes in lifestyle.

Development and management of outdoor attractions should be based on long-term spatial planning and related controlled processes. In addition to regional planning, the development of new tourism products and creative solutions tailored to specific attractions and target groups will also help facilitate the transition to sustainable travel behavior. Understanding the relationship between human socioeconomic systems and the natural environment is central in planning climate adaptation for outdoor attractions. In addition, the COVID-19 epidemic offers an opportunity to discuss the relaunch of domestic outdoor tourism in the context of experiences during the travel restrictions imposed in 2020-2021. From the current health crisis, we can learn to cope with CC-driven extreme events and increase achievements in CC adaptation.

Author Contributions: Conceptualization, S.T.R. and R.R.P.; methodology, S.T.R. and R.R.P.; software, S.T.R. and R.R.P.; validation, S.T.R. and R.R.P.; formal analysis, S.T.R.; investigation, S.T.R.; resources, S.T.R.; data curation, S.T.R.; writing—original draft preparation, S.T.R. and R.R.P.; writing—review and editing, S.T.R. and R.R.P. All authors have read and agreed to the published version of the manuscript.

Funding: This research received no external funding.

Informed Consent Statement: Not applicable.

Data Availability Statement: Available online: https:/ / doi.org/10.6084/m9.figshare.17913938 (accessed on 26 December 2021).

Acknowledgments: We thank Liran Woldman and Avi Zackai for technical assistance.

Conflicts of Interest: The authors declare no conflict of interest.

\section{Appendix A}

Table A1. Data sources.

\begin{tabular}{cc}
\hline Link & Site \\
\hline https://www.start.umd.edu/gtd/ & Global Terrorism Database \\
https://www.cbs.gov.il/he/pages/default.aspx & Central Bureau of Statistics (Israel) \\
https://www.investing.com/ & Investing \\
http://www.ims.gov.il/IMS/CLIMATE & Israel Meteorological Service \\
(accessed on 26 December 2021) & \\
\hline
\end{tabular}

\section{References}

1. IPCC. Climate Change 2021: The Physical Science Basis. In Contribution of Working Group I to the Sixth Assessment Report of the Intergovernmental Panel on Climate Change; Cambridge University Press: Cambridge, UK, 2021.

2. Chan, N.W.; Wichman, C.J. Climate Change and Recreation: Evidence from North American Cycling. Environ. Resour. Econ. 2020, 76, 119-151. [CrossRef]

3. UNWTO. COVID-19 and Tourism. 2020: A Year in Review; World Tourism Organization: Madrid, Spain, 2021.

4. UNWTO. World Tourism Barometer; World Tourism Organization: Madrid, Spain, 2021.

5. WTTC. Travel and Tourism. Economic Impact 2021; World Travel \& Tourism Council: London, UK, 2021.

6. Pröbstl-Haider, U.; Mostegl, N.; Damm, A. Tourism and climate change-A discussion of suitable strategies for Austria. J. Outdoor Recreat. Tour. 2021, 34, 100394. [CrossRef]

7. Craig, C.A.; Feng, S. A temporal and spatial analysis of climate change, weather events, and tourism businesses. Tour. Manag. 2018, 67, 351-361. [CrossRef]

8. Mendelsohn, R.; Markowski, M. The impact of climate change on outdoor recreation. In The Impact of Climate Change on the United States Economy; Cambridge University Press: Cambridge, UK, 1999; pp. 267-288.

9. Loomis, J.; Crespi, J. Estimated efects of climate change on selected outdoor recreation activities in the United States. In The Impact of Climate Change on the United States Economy; Cambridge University Press: Cambridge, UK, 1999; pp. 289-314. 
10. Rosselló-Nadal, J. How to evaluate the effects of climate change on tourism. Tour. Manag. 2014, 42, 334-340. [CrossRef]

11. Hoogendoorn, G.; Fitchett, J.M. Tourism and climate change: A Review of theats and adaptation stategies for Africa. Curr. Issues Tour. 2018, 21, 742-759. [CrossRef]

12. Priego, F.; Rossello, J.; Santana-Gallego, M. The impact of climate change on domestic tourism: A gravity model for Spain. Reg. Environ. Chang. 2015, 15, 291-300. [CrossRef]

13. Amelung, B.; Nicholls, S.; Viner, D. Implications of global climate change for tourism flows and seasonality. J. Travel Res. 2007, 45, 285-296. [CrossRef]

14. Scott, D.; Mcboyle, G.; Mills, B. Climate change and the skiing industry in southern Ontario (Canada): Exploring the importance of snowmaking as a technical adaptation. Clim. Res. 2003, 23, 171-181. [CrossRef]

15. Pintassilgo, P.; Rossello, J.; Santana-Gallego, M.; Valle, E. The economic dimension of climate change impacts on tourism: The case of Portugal. Tour. Econ. 2016, 22, 685-698. [CrossRef]

16. Kovacs, A.; Nemeth, J.; Unger, J.; Kantor, N. Tourism climatic conditions of Hungary—Present situation and assessment of future changes. Situat. Assess. Future Chang. 2017, 121, 79-99.

17. Agnew, M.D.; Palutikof, J.P. Impacts of short-term climate variability in the UK on demand for domestic and international tourism. Clim. Res. 2006, 31, 109-120. [CrossRef]

18. Day, J.; Chin, N.; Sydnor, S.; Cherkauer, K. Weather, Climate and Tourism performances: A quantative study. Tour. Manag. Perspect. 2013, 5, 51-56. [CrossRef]

19. Hamilton, J.M.; Maddison, D.; Tol, R.S. Effects of climate change on international tourism. Clim. Chang. 2005, 29, 245-254. [CrossRef]

20. Biagno, A.; Hamilton, J.M.; Tol, R.S. The impact of Climate on Holiday Destination Choice. Clim. Chang. 2006, 76, 389-406. [CrossRef]

21. Mansfeld, Y.; Freundlich, A.; Kutiel, H. The relationship between weather conditions and tourists' perception of comfort: The case of the Winter Sun Resort of Eilat. In Climate Change and Tourism-Assessmen and Coping Strategies; Amelung, B., Blazejczyk, K., Matzarakis, A., Eds.; Institute of Geography and Spatial Organization: Warsaw, Poland, 2007; pp. 116-138.

22. Bae, J.; Nam, S. An analysis of the effect of climate indicators on tourism demand: A case study of Jeju Island. J. Policy Res. Tour. Leis. Events 2020, 12, 185-196. [CrossRef]

23. Susanto, J.; Susanto, X.; Liu, Y.; Wang, C. The impacts of climate variables and climate-related extreme events on island country's tourism: Evidence from Indonesia. J. Clean. Prod. 2020, 276, 124204. [CrossRef]

24. Wilkins, E.; de Urioste-Stone, S.; Weiskittel, A.; Gabe, T. Weather sensitivity and climate change perceptions of tourists: A segmentation analysis. Tour. Geogr. 2018, 20, 273-289. [CrossRef]

25. Zebisch, M.; Grothmann, T.; Schröter, D.; Hasse, C.F. Climate change in Germany. In Vulnerability and Adaptation of Climate Sensitive Sectors; ResearchReport201; Umweltbundesamt(UBA-FB 000844/e): Dessau, Germany, 2005.

26. Atzori, R.; Fyall, A.; Miller, G. Tourist responses to climate change: Potential impacts and adaptation in Florida's coastal destinations. Tour. Manag. 2018, 69, 12-22. [CrossRef]

27. Yazdanpanah, H.; Barghi, H.; Esmaili, A. Effect of climate change impact on tourism: A study on climate comfort of. Tour. Manag Perspect. 2016, 17, 82-89. [CrossRef]

28. Landauer, M.; Pröbstl, U.; Haider, W. Managing cross-country skiing destinations under the conditions of climate changeScenarios for destinations in Austria and Finland. Tour. Manag. 2012, 33, 741-751. [CrossRef]

29. Ministry of Tourism. Available online: https://www.gov.il/he/departments/news/dovrut-1100-0005-2019-660031 (accessed on 30 December 2019).

30. CBS. Central Bureau of Statistics, Media Release. 19 September 2021. Available online: https://www.cbs.gov.il/he/mediarelease/ DocLib/2021/317/28_21_317b.pdf (accessed on 20 September 2021).

31. Zoccatelli, D.; Marra, F.; Armon, M.; Rinat, Y.; Smith, J.; Morin, E. Contrasting rainfall-runoff characteristics of floods in desert and Mediterranean basins. Hydrol. Earth Syst. Sci. 2019, 23, 2665-2678. [CrossRef]

32. IMS. Available online: https://ims.data.gov.il/ims/1 (accessed on 21 December 2021).

33. Aufhammer, M.; Hsiang, S.M.; Schlenker, W.; Sobel, A. Using weather data and climate model output in economic analyses of climate change. Rev. Environ. Econ. Policy 2013, 7, 181-198. [CrossRef]

34. Hoffman, M. Inbound Tourism Survey Annual Report 2019; Israel Ministry of Tourism: Jerusalem, Israel, 2020.

35. Investing. Available online: https://il.investing.com/webmaster-tools/exchange-rates-table (accessed on 26 December 2021).

36. Israel Government Portal. Available online: https://globaledge.msu.edu/global-resources/resource/5838 (accessed on 26 December 2021).

37. Central Bureau of Statistics (Israel). Available online: https://www.cbs.gov.il/he/pages/default.aspx (accessed on 26 December 2021).

38. Massidda, C.; Etzo, I. The determinants of Italian domestic tourism: A panel data analysis. Tour. Manag. 2012, 33, 603-610. [CrossRef]

39. Bao, J.; Xie, H.J. Determinants of domestic tourism demand for Guilin. J. China Tour. Res. 2019, 15, 1-14. [CrossRef]

40. Schmude, J.; Karl, M.; Weber, F. Tourism and Terrorism: Economic impact of terrorist attacks on the tourism industry. The example of the destination of Paris. Z. Wirtsch. 2020, 64, 88-102. 
41. Hayat, U. The Dynamic Effects of Terrorism on Tourism: A Bound Testing Co-integration Approach. IBT J. Bus. Stud. 2020, 16, 44-57.

42. Global Terrorism Database. Available online: https:/ /www.start.umd.edu/gtd/search / Results.aspx?search=\&sa.x=54\&sa.y=3 (accessed on 1 August 2021).

43. Ministry of Tourism. Available online: https://info.goisrael.com/he/\%D7\%A1\%D7\%A7\%D7\%A8- \%D7\%AA\%D7\%99\%D7\%99\% D7\%A8\%D7\%95\%D7\%AA-\%D7\%A0\%D7\%9B\%D7\%A0\%D7\%A1\%D7\%AA-\%D7\%9C\%D7\%A9\%D7\%A0\%D7\%AA-2016-pdf2 (accessed on 2 August 2021).

44. The Society for the Protection of Nature in Israel. Israel National Trail. Available online: https://natureisrael.org/INT (accessed on 28 January 2022). 